\title{
A comparison of total precipitable water measurements from radiosonde and sunphotometers
}

\author{
Elies Campmany ${ }^{\mathrm{a}, *}$, Joan Bech ${ }^{\mathrm{b}}$, Javier Rodríguez-Marcos ${ }^{\mathrm{a}, 1}$, Yolanda Sola ${ }^{\mathrm{a}}$, Jerónimo Lorente ${ }^{\mathrm{a}}$ \\ ${ }^{a}$ Dept. Astronomia i Meteorologia, Universitat de Barcelona, Martí i Franquès 1, Barcelona 08028, Spain \\ b Servei Meteorològic de Catalunya, Berlin 38-48 4a, Barcelona 08029, Spain
}

\section{A R T I C L E I N F O}

\section{Article history:}

Received 2 June 2009

Received in revised form 23 April 2010

Accepted 29 April 2010

Available online $\mathrm{xxxx}$

\section{Keywords:}

Total precipitable water

Radiosonde

Sunphotometer

Cimel

Microtops

\section{Introduction}

The knowledge of accurate values of water vapour present in the atmosphere is essential for the monitoring and forecasting tasks of most meteorological processes. The horizontal and vertical distributions of water vapour are also important factors for understanding the hydrological cycle variations and climate change and global warming studies, as water vapour is the most abundant greenhouse gas.

\footnotetext{
* Corresponding author. Present address: Earth Sciences Dept., Barcelona Supercomputing Center, Jordi Girona 29, Barcelona 08034, Spain. Tel.: + 34 934134038.

E-mail address: elies.campmany@bsc.es (E. Campmany).

1 Present address: Agencia Estatal de Meteorología, CMT Aragón, La Rioja y Navarra, Spain.
}

During decades the traditional instrument used to measure 51 the water vapour vertical profile has been the radiosonde. 52 However, this has some limitations, such as imprecision in the 53 estimation of moisture due to different causes like the freezing 54 of moisture sensors, the release of latent heat, the phase lag 55 between dry and wet bulb sensors. Measurements of moisture 56 profile from radiosondes allow estimating the total precipitable 57 water (TPW), i.e., the integrated amount of water vapour in the 58 vertical column from the ground to the top of the atmosphere, 59

$$
T P W=\frac{1}{g} \sum_{i=1}^{n} q_{i} \Delta p_{i}
$$

where $g$ is the acceleration due to gravity, $n$ is the number of 60 atmospheric layers considered and $q_{i}$ is the mean specific 62 humidity corresponding to atmospheric layer $i$ with a pressure 63

0169-8095/\$ - see front matter (C) 2010 Elsevier B.V. All rights reserved. doi:10.1016/j.atmosres.2010.04.016 
increment $\Delta p_{i}$. TPW, also known as water (vertical) column abundance, is normally expressed in $\mathrm{kg} \mathrm{m}_{\mathrm{s}}^{-2}$ (or its equivalent depth in $\mathrm{mm}$ if all water vapour in the column was condensed). The specific humidity is not a direct measurement of the radiosonde but can be written in terms of the dew point temperature.

When a global distribution of water vapour is considered, the radiosonde measurements are generally insufficient because of their irregular and poor spatial and temporal coverage. Other type of water vapour measurements, like those based on satellite observations, including retrievals from Global Positioning System (GPS) measurement, or ground based radiometers can complement radiosonde derived TPW observations (Stoew et al., 2001; Dostalek and Schmit, 2001; Chaâbane et al., 2006; Martinez et al., 2007).

Because of its simplicity and its lower cost TPW can be obtained from sunphotometers when direct sunlight reaches the ground. They are simple to use and offer a higher spatial and temporal resolution than radiosounding data, but less coverage than from satellite measurements. Since the use of these instruments requires cloudless conditions at least in front of the sun, sunphotometers measurements are biased toward cloud-free conditions. The uncertainty of TPW from sunphotometers is mainly due to some aging effects in the filters incorporated in these instruments, which can be analyzed by comparison (Plana-Fattori et al., 1998).

Comparisons between TPW values obtained from radiosondes and sunphotometers have been carried out in different places. For example, Halthore et al. (1997) made a comparison between Cimel sunphotometer and radiosonde data with simultaneous measurements during clear-sky conditions (July 1993) at Wallops Island, Virginia (US). The results showed differences of $10 \%$ in TPW between radiosonde and sunphotometer data (the latter with lower values). The same authors made a comparison between the same instruments in the Atmospheric Radiation Measurement (ARM) project (Oklahoma, US) in April 1994 and obtained that the sunphotometer overestimated the TPW derived from radiosonde by about $9.2 \%$. Revercomb et al. (2003) reported differences up to $15 \%$ between radiosonde and MicroWave Radiometer (MWR) with the radiosonde typically being drier than the MWR in a 2-year comparison of measurements conducted at the ARM site in Oklahoma between 1996 and 2000.

The main objective of this paper is the comparison of TPW values obtained simultaneously during the period 2001-2004 over the same point of observation from the radiosonde and two kind of sunphotometers currently employed in the solar measurement networks, the Microtops II and Cimel instruments. In addition, a preliminary climatology of the TPW during this period is presented.

\section{Data}

\subsection{Radiosonde}

Since 1997, radiosonde observations have been made at the Astronomy and Meteorology Department of the University of Barcelona $\left(41^{\circ} 23^{\prime} \mathrm{N}, 2^{\circ} 7^{\prime} \mathrm{E}\right.$ and $98 \mathrm{~m}$ above sea level) to support the operations of the regional administration's Subdirectorate of Air Quality and Meteorology. Observations are performed operationally twice a day at 00 and 12 UTC (00 and 12 LST) using Vaisala RS-80A sondes. Measurements, 122 recorded every $10 \mathrm{~s}$., include temperature, pressure, relative 123 humidity and wind speed and direction.

As radiosonde data are available for relative long time 125 series, they are the traditional source for upper-air climato- 126 logical studies, for example devoted to characterise humidity 127 conditions (Elliot and Gaffen, 1991) or temperature (Luers 128 and Eskridge, 1995; Zhai and Eskridge, 1996). However, some 129 potential instrumental problems and environmental factors 130 may affect the quality and representativeness of measure- 131 ments, particularly, but not only, in the lowest layers of the 132 troposphere (Parlange and Brutsaert, 1990; Connel and 133 Miller, 1995; Free et al., 2002). For example, recent efforts 134 to build global re-analysis data sets have considered different 135 methods to correct radiosonde systematic temperature bias, 136 including satellite observations such as the NOAA Vertical 137 Profile Radiometer (Andrae et al., 2004; Li et al., 2005).

According to Bruegge et al. (1992) total water vapour 139 estimated with radiosonde measurements presents three 140 main sources of error: (a) overestimate of moisture after 141 freezing and subsequent latent heat release (which may 142 introduce up to 8\% errors); (b) different time lags between 143 dry and wet bulb temperature measurements (up to 6\% 144 errors); and (c) higher atmospheric layers not sampled by 145 radiosonde ascents (up to 8\% errors). Other authors, as 146 Miloshevich et al. (2006), suggest a maximum of 6-8\% dry 147 bias daytime measurements due to the solar heating of the 148 sensor. In our data set, the correction suggested in that study 149 yielded differences mostly $<1 \%$ so this was finally not applied. 150

\subsection{Sunphotometer Microtops II}

The Microtops II v.2.4X is a multi-band sunphotometer 152 capable of measuring the total ozone column, the TPW and the 153 aerosol optical thickness at $1020 \mathrm{~nm}$ (Morys et al., 2001). The 154 instrument is equipped with 5 optical collimators with a full 155 field of view (FOV) of $2.5^{\circ}$. Each channel is fitted with an 156 interference filter and a photodiode that produces an electrical 157 current proportional to the measured power. The instrument 158 measures the direct beam of the solar irradiance in the 159 wavelengths of $305.5,312.5,320.0,936.0$ and $1020.0 \mathrm{~nm}$ with 160 a full width at half maximum (FWHM) of $2 \pm 0.3 \mathrm{~nm}$ for the 3161 channels of the UV region and a FWHM of $10 \pm 1 \mathrm{~nm}$ for the 162 other two.

The instrument is calibrated with Langley plots from 164 Mauna Loa (Hawaii, $3397 \mathrm{~m}$ a.s.l) recorded under different 165 meteorological conditions. The retrieval of the TPW is based 166 on measurements taken at $936 \mathrm{~nm}$ (water absorption peak) 167 and $1020 \mathrm{~nm}$ (no water absorption). Because of the nonlinear 168 dependence of the atmospheric transmission on TPW, the 169 response voltage $V_{936}$ of the sunphotometer is given by the 170 Modified Beer Law (Reagan et al., 1987; Bruegge et al., 1992): 171

$\ln V_{936}+m \tau_{\text {scat }}=\ln V_{0}-a(w m)^{b}$

where $\tau_{\text {scat }}$ is the sum of the Rayleigh and aerosol optical 173 depths $\left(\tau_{\mathrm{a}}\right)$ contributions in the 936-nm channel, $m$ is the air 174 mass and $w$ is the total precipitable water (TPW). The 175 parameters $a$ and $b$ are adjustable constants depending on the 176 instrument characteristics (i.e. the bandwith of the filter) and 177 the atmospheric conditions (i.e., pressure, temperature and 178 
vertical distribution of water vapour). These constants are generally determined using a radiative transfer model (Halthore et al., 1997; Alexandrov et al., 2009). The values of both constants are introduced in the instrument by the manufacturer ( $a=0.7847$ and $b=0.5945$ ).

The determination of the TPW requires the aerosol optical depth contribution at $936 \mathrm{~nm}$. This value is not calculated by the instrument but it is derived from the aerosol optical depth at $1020 \mathrm{~nm}$, internally computed following the Beer's law. From a radiative transfer model, a relationship between the aerosol optical depths at both wavelengths is found for a standard atmosphere and it is assumed constant for other conditions. For the Microtops filters the relationship is $\tau_{\mathrm{a} 936}=1.16 \tau_{\mathrm{a} 1020}$ (Morys et al., 2001).

\subsection{Sunphotometer Cimel}

The Cimel 318N-VBS7 is a motor-tracked sunphotometer which points automatically to the Sun (Cimel, 2001). This instrument is the standard Sun/sky photometer from the AErosol RObotic NETwork (AERONET) (Holben et al., 1998). It has an optical header with two collimators (a glassless one to observe the Sun and another with glasses to observe the sky). The whole FOV is $1.2^{\circ}$. This header points to the Sun using two microprocessors that calculate the zenithal and azimuthal angle from the geographical coordinates and the date and time. The orientation is finally sharpened with a four-quadrant detector with a precision of $0.1^{\circ}$. The instrument has 7 channels 340,380 , $440,675,870,936$ and $1020 \mathrm{~nm}$ with a FWHM of $10 \mathrm{~nm}$ (except for the channels of 340 and $380 \mathrm{~nm}$ which have a FWHM of $2 \mathrm{~nm}$ ). Cimel instrument measures the direct irradiance, the almucantar irradiance (i.e., observed along a circle parallel to the horizon at a given elevation angle) and the principal plane irradiance (over an arc of varying elevation angle given a fix azimuth) at the Earth's surface. For each measurement the instrument covers all 7 filters in $8 \mathrm{~s}$ and after a break of $20 \mathrm{~s}$, it repeats the series two times more; therefore for either channel there are 3 non-simultaneous measurements available. The direct sun triplets are used to perform cloud discrimination and stability controls following the AERONET standard algorithm (Smirnov et al., 2000).
The Cimel instrument was calibrated by the Langley tech- 218 nique using the most stable days of the data set with air masses 219 varying from 2 to 6 . For the 936-nm filter, the calibration was 220 determined using the "modified Langley plot,", taking loga- 221 rithms at both sides of Eq. (2). As it was explained for the 222 Microtops algorithm description, the pair of constants $a$ and $b 223$ are numerically derived based on the modelled spectral irra- 224 diances at $936 \mathrm{~nm}$. Halthore et al. (1997), using the MODTRAN- 225 3 radiative transfer (RT) model, determined $a$ and $b$ for the 226 Cimel CE318 filters. In this work we have used these constants 227 differing between summer $(a=0.616, b=0.593)$ and winter 228 $(a=0.616, b=0.597)$.

Schmid et al. (2001) showed that the use of a single RT 230 model produces a spread of $0.22 \mathrm{~cm}(8 \%)$ in TPW among 231 different types of solar radiometers. In the same way, 232 Alexandrov et al. (2009) presented a detailed analysis of the 233 errors in TPW retrieval due to uncertainties in the calibration, 234 in the instrument filter profiles and water vapour absorption 235 line parameters in HITRAN spectral database. The estimated 236 uncertainties in multifilter rotating shadowband radiometer 237 (MFRSR) associated with calibration, spectral response filter 238 (SRF) and spectral databases were 4.5\%, 4.4\% and 5\%, 239 respectively for solar noon in summer.

\section{Results and discussion}

Fig. 1 shows the TPW retrieved using radiosonde, Micro- 242 tops and Cimel sunphotometer. The radiosonde data is the 243 longest and most continuous series of the three instruments 244 and includes 3.5 years of data. TPW has a seasonal behaviour 245 with a maximum in summer and a minimum in winter. This is 246 due to the fact that a higher air temperature implies a larger 247 capacity to store water vapour without saturation. Maximum 248 values reach $42 \mathrm{~mm}$ and minimum values around $2 \mathrm{~mm}$. The 249 range between the maximum and the minimum values for 250 the same season is approximately constant, around $25 \mathrm{~mm}$. 251

The TPW measured by the sunphotometer Microtops is 252 more discontinuous than the previous one because the in- 253 strument needs cloud-free conditions, at least between the sun 254 and the sunphotometer, to discern the solar disk (DeFelice and 255 Wylie, 2001). However, the period of the series is long enough 256

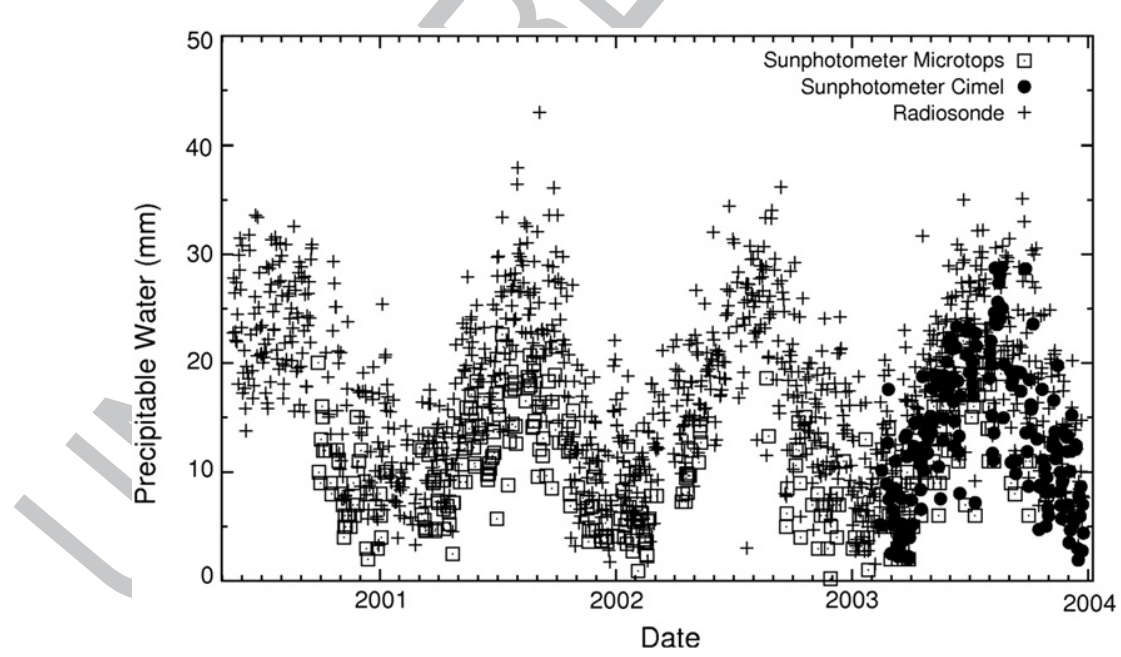

Fig. 1. Comparison between total precipitable water retrieved by radiosonde, Microtops and Cimel data recorded in Barcelona. 
to appreciate the same seasonal behaviour deduced in the first series. In this case, the maximum value reaches $22 \mathrm{~mm}$ and the minimum is almost 0 . The range is not as constant as in the radiosonde data and is approximately equal to $10 \mathrm{~mm}$. There is a gap in the summer of 2002 because the instrument was used in a field campaign in Southern Spain (Alados-Arboledas et al., 2003; Sola et al., 2008).

The TPW retrieved from the Cimel data corresponds to 2003 (the instrument was installed in January of the same year). Although the instrument performs several measurements during daytime, only the value closer to midday is plotted to ensure maximum simultaneity with the other measurements. A cloud screening filter has been applied using the quality control of the AERONET database (Smirnov et al., 2000). The same seasonal pattern noticed in the radiosonde and the Microtops sunphotometer is present in this series. In this case the maximum value reaches $35 \mathrm{~mm}$ and the minimum is almost $0 \mathrm{~mm}$. Data range is roughly constant as well, approximately $15 \mathrm{~mm}$.

Intra-annual range is quite regular, approximately $15 \mathrm{~mm}$. Most of the upper points correspond to radiosonde data, while in the lower part of the graph there is a greater amount of Microtops data. This can be explained by the fact that radiosonde data shown in Fig. 1 include cloudy days with typically higher values of TPW.

Table 1 shows the temporal period covered, the total number of data available, and the average and standard deviation of TPW retrieved with each instrument. In the case of Cimel photometer, only one measurement per day has been considered. The number of concurrent or simultaneous measurements available for the three instruments is relatively small in comparison with the total number of data available for each single instrument. The mean for the radiosonde and Cimel data is substantially lower in the simultaneous measurements than considering the whole data sets. This can be explained considering that a coincident measurement is always in a sunny period (with less water vapour content in the atmosphere than in a cloudy day) since the Microtops photometer only performs measurements under cloudless conditions. No attempt was made to study TPW temporal trends as the time series were too limited for that purpose.

The time of the radiosonde measurements is local noon (launch time). Although a radiosonde takes about one hour and a half to acquire all the data, the boundary layer, where most water vapour is present, is sampled just after launch. At launch time (12 UTC) a manual Microtops sunphotometer measurement was carried out at the same place of the launching. In

Table 1

Period covered, number of data available, average and standard deviation of total precipitable water retrievals for each single instrument (radiosonde and Microtops and Cimel sunphotometers) and for simultaneous measurements (last row).

\begin{tabular}{llll}
\hline & Radiosonde & Microtops & Cimel \\
\hline Period & May2000- & Sep2000- & Feb2003- \\
& Dec2003 & Nov2003 & Dec2003 \\
Number of data & 1225 & 490 & 184 \\
Mean \pm std dev $(\mathrm{mm})$ & $17 \pm 8$ & $10 \pm 5$ & $13 \pm 7$ \\
Mean \pm std dev $(\mathrm{mm})$ & $15 \pm 7$ & $11 \pm 5$ & $12 \pm 7$ \\
$\quad$ for simultaneous & & & \\
$\quad$ measurements (57) & & & \\
\hline
\end{tabular}

the case of the Cimel sunphotometer, which operates automat- $30 \mathrm{~g}$ ically at the same launching site, the measurement closer to 319

12 UTC has been considered.

No cloud screening filter was applied to the radiosonde 321 data. Fig. 1, which shows 12 UTC values, exhibits a rather con- 322 tinuous plot. On the contrary, sunphotometer data are more 323 discontinuous due to the fact that in that case only clear-sky 324 observations are available.

In order to quantify and evaluate the differences among 326 the three instruments, linear fits between pairs of them have 327 been calculated (Fig. 2). Fig. 2a shows the least square line fit 328 between Microtops and radiosonde data. The radiosonde 329 retrievals have higher values than the Microtops-derived 330 water vapour estimations. However it can be appreciated that 331 both retrievals are strongly correlated. Fig. 2b shows the linear 332 fit between Cimel and radiosonde data. In this case the slope is 333 almost equal to 1 , which indicates a very good agreement 334
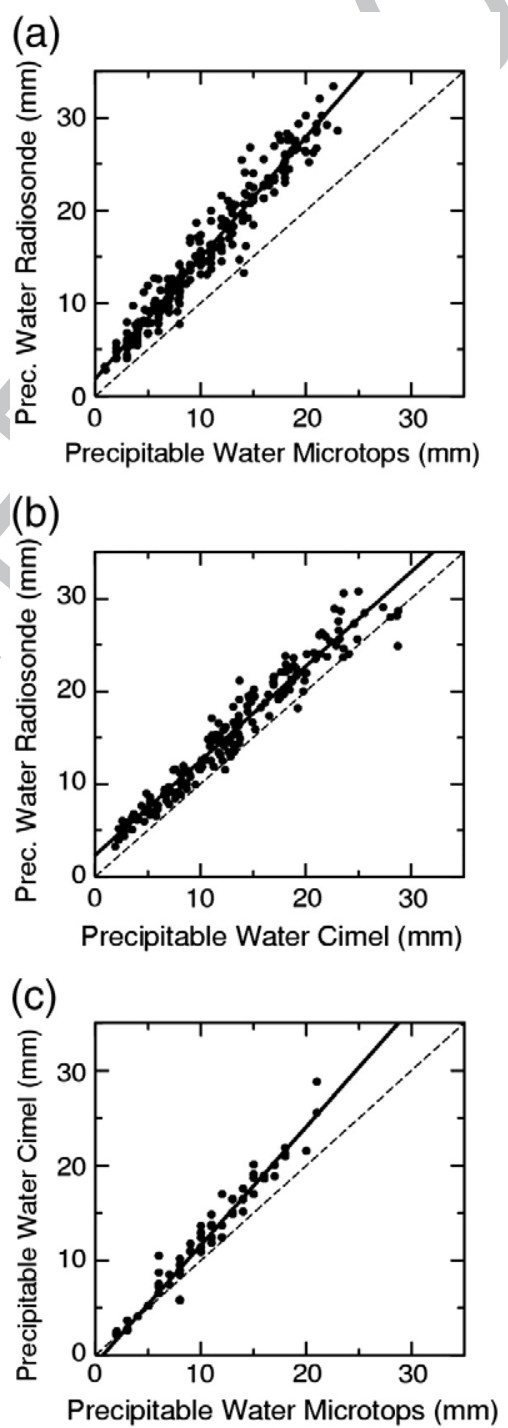

Fig. 2. Least squares linear fits between water vapour retrievals obtained with the following datasets: (a) Microtops-Radiosonde; (b) Cimel-Radiosonde; and (c) Microtops-Cimel. 
Table 2

Least squares linear fit $y=a x+b$, between total precipitable water retrieved from radiosonde and two sunphotometers (Microtops and Cimel) data.

\begin{tabular}{llll}
\hline & $\begin{array}{l}\text { Microtops }(x)- \\
\text { Radiosonde }(y)\end{array}$ & $\begin{array}{l}\text { Microtops } \\
(x) \text {-Cimel }(y)\end{array}$ & $\begin{array}{l}\text { Cimel }(x)- \\
\text { Radiosonde }(y)\end{array}$ \\
\hline$a$ & $1.30 \pm 0.02$ & $1.25 \pm 0.03$ & $1.02 \pm 0.02$ \\
$b$ & $1.8 \pm 0.2$ & $-0.8 \pm 0.4$ & $2.3 \pm 0.3$ \\
$r^{2}$ & 0.945 & 0.943 & 0.947 \\
N. points & 235 & 78 & 180 \\
\hline
\end{tabular}

between both retrievals. Since the radiosonde also gives higher values of TPW it produces the highest water vapour estimates of the 3 instruments.

Finally, Fig. 2c exhibits the linear fit between the 2 sunphotometers. Though it is the fit with less number of points, it can be appreciated that both variables are well correlated. However, Microtops values are lower than Cimel TPW with the deviation increasing as the TPW increases. This behaviour is probably due to the value of the $a$ constant (Eq. (2)) set by the manufacturer $(a=0.7847)$ which might be inexact. Ichoku et al. (2002) determined a new empirically-derived $a$ value of 0.615 that is very close to the constant determined for the Cimel filter by Halthore et al. (1997) and used in this work. With the new $a$ value and new calibration coefficients, Ichoku et al. (2002) found an improvement in RMSE between Cimel and Microtops TPW-derived $(<0.1 \mathrm{~cm})$. Another source of inaccuracy is the way the internal Microtops algorithm determines $\tau_{\mathrm{a} 936}$ as $1.12 \tau_{\mathrm{a} 1020}$, assuming this relationship is always constant.

The water vapour retrieved by Cimel is higher than the one measured by Microtops such as in the Microtopsradiosonde comparison, hence Microtops measurements provide the lowest water vapour estimations of the 3 instruments. Table 2 shows the coefficients of the 3 least square line fits
Table 3

Mean Bias Error (MBE) and Root Mean Square Error (RMSE) of relative and absolute differences among the 3 total precipitable water retrievals: Microtops-Radiosonde, Microtops-Cimel and Cimel-Radiosonde.

\begin{tabular}{lllllll}
\hline & \multicolumn{2}{c}{ Absolute differences } & & \multicolumn{2}{c}{ Relative differences } \\
\cline { 2 - 3 } \cline { 6 - 7 } & MBE [mm] & RMSE [mm] & & MBE [\%] & RMSE [\%] \\
\hline Microtops-Radiosonde & -5.37 & 3.76 & & -35.32 & 21.94 \\
Microtops-Cimel & 1.97 & 1.71 & & 17.41 & 14.84 \\
Cimel-Radiosonde & -2.62 & 1.76 & & -18.97 & 12.29
\end{tabular}

and their correlation. The best fit is for the comparison bet- 359 ween Cimel and radiosonde (Fig. 2b) which obtains a 360 correlation factor of 0.947 .

Fig. 3 shows the relative and absolute differences between 362 couples of the 3 instruments. It is remarkable that the dif- 363 ferences between Microtops and radiosonde retrievals have 364 the highest values in both relative and absolute terms. In this 365 case, the differences are mainly negative, which confirm the 366 results shown in Fig. 2a. However, there are some positive 367 values that are considerably high, especially in the relative 368 differences plot. The maximum value for the absolute dif- 369 ferences is around $20 \mathrm{~mm}$ and for the relative ones around 370 $75 \%$. These great differences between Microtops and radio- 371 sonde retrievals have been reflected in the BIAS and the 372 RMSE shown in Table 3, which are the highest for the 3373 comparisons.

Considering the differences between Microtops and Cimel, 375 these are mainly positive in concordance with Fig. 2c. In this 376 case the differences have lower values (the maximum relative 377 difference is around $50 \%$ and the absolute is $5 \mathrm{~mm}$ ) and the 378 BIAS and the RMSE show a better agreement as well.

Finally, the difference between Cimel and radiosonde is 380 mainly negative as could be expected from Fig. $2 \mathrm{~b}$, and it can 381 be appreciated a lower relative difference in summer, since 382
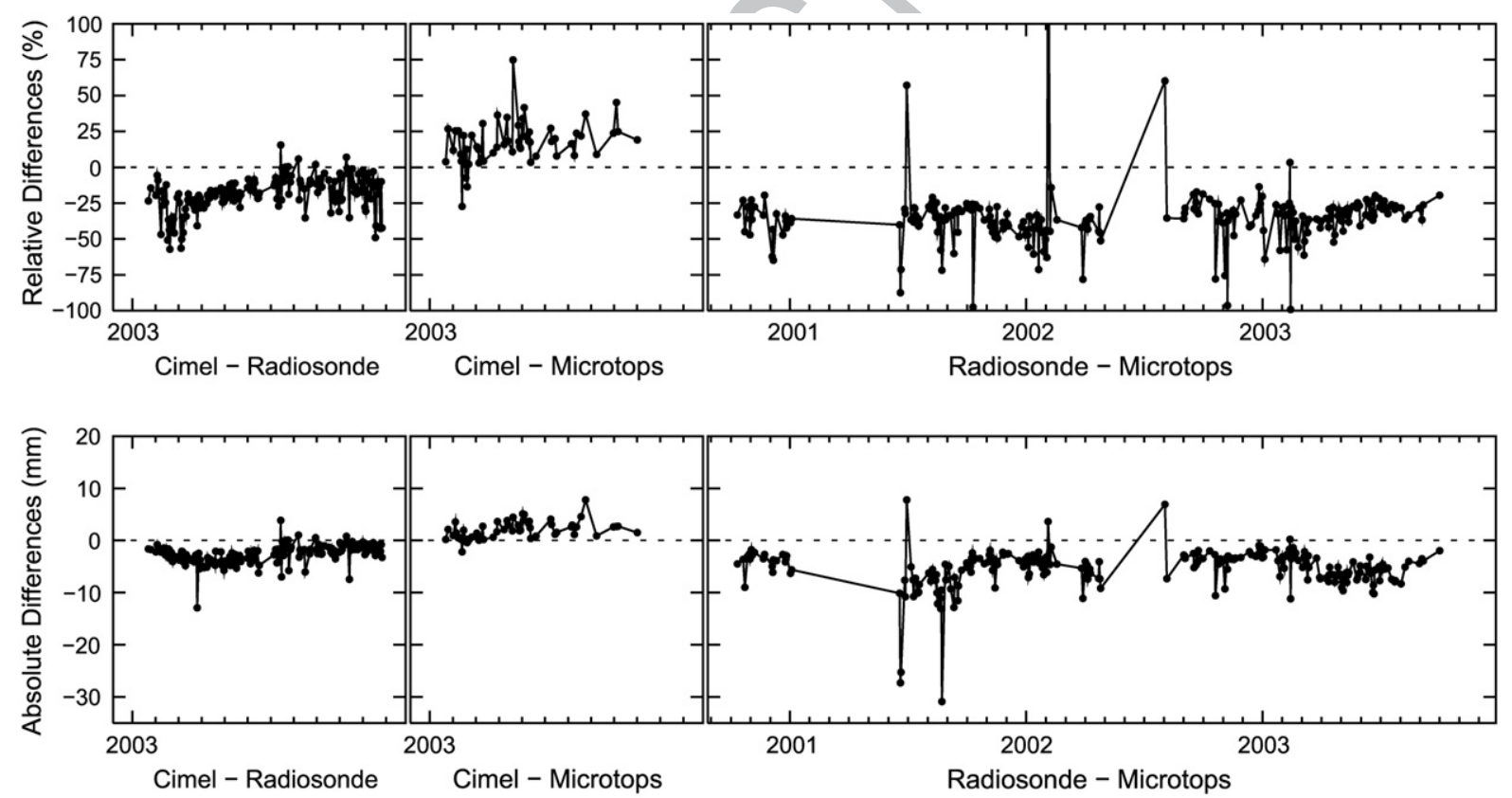

Fig. 3. Time series of absolute and relative differences among Radiosonde, Microtops and Cimel data recorded in Barcelona. 

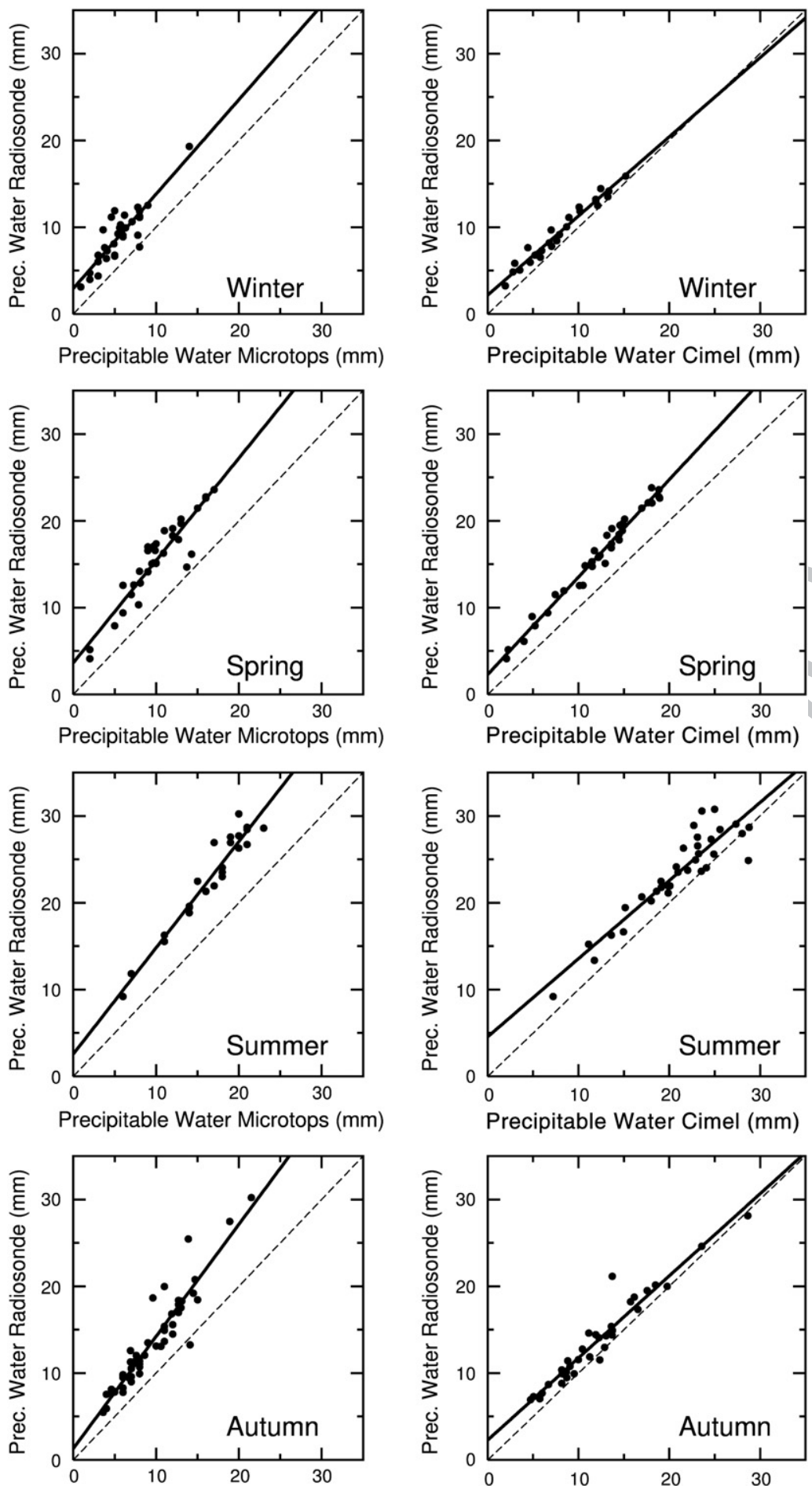

Precipitable Water Microtops $(\mathrm{mm})$

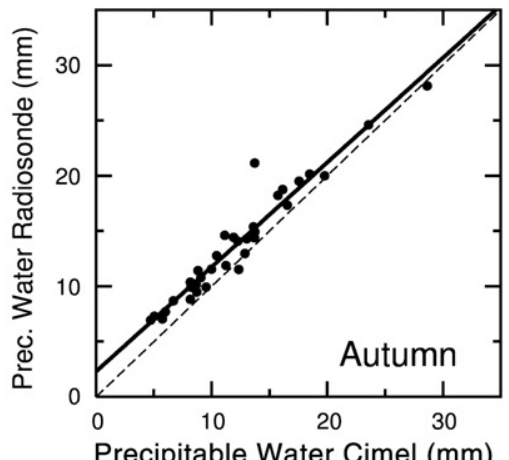

Fig. 4. Least squares linear fits between Radiosonde and the sunphotometers water vapour retrievals for different seasons: winter (December and February), spring (April and May), summer (July and August) and autumn (October and November).

the value of the TPW in the denominator is greater. The maximum of these differences is around $50 \%$ for the relative ones and for the absolute ones around $10 \mathrm{~mm}$. However the BIAS and the RMSE show good agreement. RMSE of these relative differences (shown in Table 3) exhibits a value of 387 $12.29 \%$, close to the $10 \%$ proposed by Halthore et al. (1997) in 388 the comparison between Cimel and radiosonde data at 389 Wallops Island, mentioned above. 
Table 4

Least squares linear fit $y=a x+b$, between total precipitable water retrieved by radiosonde and by two sunphotometers (Microtops and Cimel).

$\mathrm{t} 4.2$

$\mathrm{t} 4.3$

$\mathrm{t} 4.4$

$\mathrm{t} 4.5$

$\mathrm{t} 4.6$

t4.7

$\mathrm{t} 4.8$

\begin{tabular}{llllll}
\hline Instrument & Season & $a$ & $b$ & $r^{2}$ & \# points \\
\hline Microtops $(x)-$ & Winter & $1.10 \pm 0.10$ & $2.9 \pm 0.7$ & 0.83 & 31 \\
Radiosonde $(y)$ & Spring & $1.18 \pm 0.08$ & $3.6 \pm 0.9$ & 0.89 & 34 \\
& Summer & $1.22 \pm 0.07$ & $2.0 \pm 1.0$ & 0.94 & 24 \\
Cimel $(x)-$ & Autumn & $1.29 \pm 0.07$ & $1.3 \pm 0.7$ & 0.85 & 50 \\
Radiosonde $(y)$ & Winter & $0.91 \pm 0.04$ & $2.2 \pm 0.3$ & 0.83 & 26 \\
& Spring & $1.10 \pm 0.03$ & $2.3 \pm 0.4$ & 0.87 & 34 \\
& Summer & $0.90 \pm 0.07$ & $5.0 \pm 1.0$ & 0.94 & 35 \\
& Autumn & $0.94 \pm 0.05$ & $2.3 \pm 0.6$ & 0.85 & 34 \\
\hline
\end{tabular}

Fig. 4 and Table 4 show the correlations between radiosonde data and the sunphotometers for different seasons (December and February for winter, April and May for spring, July and August for summer and October and November for autumn). The seasonal behaviour mentioned before is also present especially in the winter plot where all the points have low values, and in the summer plot with higher values. Table 4 shows that the value of the slope and correlations change slightly with the season. In case of the Microtops and radiosonde comparison, the slope oscillates between 1.10 (winter) and 1.29 (autumn) while in the case of the Cimel and radiosonde comparison the oscillation is between 0.90 (summer) and 1.10 (spring). The variations in the correlations only vary significantly (with a confidence level $p=0.05$ ) between Cimel and radiosonde data during summer and winter and summer and autumn; the rest of variations are not significant.

\section{Summary and conclusions}

Total precipitable water measurements from radiosonde and two different sunphotometers (Cimel and Microtops instruments) have been carried out and compared in Barcelona, Spain. The length of the time series examined spanned from 3.5 years (radiosonde data) to 11 months (Cimel sunphotometer); 57 simultaneous measurements for the three instruments were available in cloudless conditions and a higher number was used for comparison between two instruments. Results show a similar seasonal pattern of the three time series with a maximum in summer, a minimum in winter and an intra-annual range about $15 \mathrm{~mm}$. The radiosonde data show generally higher TPW values (on average $15 \mathrm{~mm}$ for the simultaneous measurements), and a better agreement with the Cimel sunphotometer. The finding of higher values of TPW measured by radiosondes compared to photometers is qualitatively in agreement with previous studies, as that by Halthore et al. (1997) performed at Wallops Island (US), though there are some differences in the methodology of both studies which hampers a detailed comparison.

The two time series of the sunphotometers are well correlated, but average TPW values from Cimel are slightly higher $(12 \mathrm{~mm})$ than those corresponding to Microtops II $(11 \mathrm{~mm})$; the RMSE between the TPW of the photometers is $<2 \mathrm{~mm}$. In most cases the correlations between instruments did not change substantially in different seasons - i.e. with higher or lower TPW values. This is an interesting result considering that in other studies comparing several instruments measuring TPW - for example that of Liou et al. (2001) using radiosondes and GPS-based techniques near the Tropics, - a dependence on 437 the amount of TPW of the differences between instruments 438 was found.

As the period examined is relatively short to study 440 possible TPW trends, this aspect was not considered in this 441 research. However, other studies with larger datasets gener- 442 ally indicate increasing TPW amounts. For example, a 443 variation of a little less than $1 \%$ per year was found over 444 Boulder (US) over a 14-year period (AGU, 1995), in 445 agreement with Ross and Elliott (1996) who found an in- 446 crease of 3-7\% per decade of TPW for trends south of $45^{\circ} \mathrm{N}$ in 447 North America. Ross and Elliott (2001) and Trenberth et al. 448 (2005) found later similar results for the whole Northern 449 Hemisphere. The study of possible TPW trends in Barcelona is 450 therefore left for future research when longer time series will 451 be available for further analysis.

\section{Acknowledgment}

This work was supported by the Spanish Ministry of 454 Science and Technology under the project DAMOCLES 455 'Aerosols characterization by columnar (lidar and extinction) 456 and "in situ" measurements' (REF: CGL2005-03428-C04-04). 457

\section{References}

AGU, 1995. Water Vapor in the Climate System. AGU Special Report. 459 American Geophysical Union, 2000 Florida Ave., N.W., Washington, DC 460 20009.

Alados-Arboledas, L., et al., 2003. VELETA 2002 field campaign. Geophys. Res. 462 Abst. 5, 12,218.

Alexandrov, M.D. Schmid, B., Turner, D.D., Cairns, B., Oinas, V., Lacis, A. A 464 Gutman, S.I., Westwater, E.R., Smirnov, A., Eilers, J., 2009. Columnar 465 water vapor retrievals from multifilter rotating shadowband radiometer 466 data. J. Geophys. Res. 114, D0230610.1029/2008JD010543. 467

Andrae, U., Sokka, N., Onogi, K., 2004. The radiosonde temperature bias 468 corrections used in ERA-40. ERA-40 Project Report Series 15. European 469 Centre for Medium-Range Weather Forecasts, 34 pp. 470

Bruegge, C.J., Conel, J.E., Green, R.O., Margolis, J.S., Holm, R.G., 1992. Water 471 vapor column abundance retrievals during FIFE. J. Geophys. Res. 97472 (D17), 18,759-18,769.

Chaâbane, M., Masmoudi, M., Medhioub, K., Elleuch, F., 2006. Daily and 474 monthly averaged aerosol optical properties and diurnal variability 475 deduced from AERONET sun-photometric measurements at Thala site 476 (Tunisia). Meteorol. Atmos. Phys. 92, 103-114. 477

Cimel, 2001. Sunphotometer User Manual Cimel CE 318, V. 4.6, Cimel. 172478 rue de Charonne, 75011 Paris, France, 79 pp.

Connel, B.H. Miller, D.R. 1995. Interpretation of radiosonde errors in the 480 atmospheric boundary layer. J. Appl. Meteor. 34, 1070-1081.

DeFelice, T.P., Wylie, B.K., 2001. Sky type discrimination using a ground- 482 based sun photometer. Atmos, Res. 59-60, 313-329. 483

Dostalek, J.F., Schmit, T.J., 2001. Total precipitable water measurements from 484 GOES sounder derived product imagery. Wea. Forecast. 16, 573-587. 485

Elliot, W.P., Gaffen, D.J., 1991. On the utility of radiosonde humidity archives 486 for climate studies. Bull. Amer. Meteor. Soc. 72, 1507-1520. 487

Free, M., et al., 2002. Creating climate reference datasets: CARDS workshop 488 on adjusting radiosonde temperature data for climate monitoring. Bull. 489 Amer. Meteor. Soc. 83, 891-899.

Halthore, R.N. Eck, T.F. Holben, B.N. Markham, B.L. 1997. Sun photometric 491 measurements of atmospheric water vapor column abundance in the 492 940-nm band. J. Geophys. Res. 102 (D4), 4343-4352. 493

Holben, B.N., et al., 1998. AERONET - a federated instrument network and 494 data archive for aerosol characterization. Remote Sens. Environ. 106495 (D11), 12,067-12,097.

Ichoku, C., Levy, R., Kaufman, Y.J., Remer, L.A., Li, R.-R., Martins, V.J., Holben, B. 497 N., Abuhassan, N., Slutsker, I., Eck, T.F., Pietras, C., 2002. Analysis of the 498 performance characteristics of the five-channel Microtops II Sun 499 photometer for measuring aerosol optical thickness and precipitable 500 water vapor. J. Geophys. Res. 107 (D3), 417910.1029/2001JD001302. 501 
Li, X., Kelly, G., Uppala, S., Saunders, R., Gibson, J.K., 2005. The use of VTPR raw radiances in ERA-40. ERA-40 Project Report Series 21. European Centre for Medium-Range Weather Forecasts. 20 pp.

Liou, Y.A., Teng, Y.T., Van Hove, T., Liljegren, J.C., 2001. Comparison of precipitable water observations in the near tropics by GPS, microwave radiometer, and radiosondes. J. Appl. Meteorol. 40, 5-15.

Luers, J.K., Eskridge, R.E., 1995. Temperature correction for the VIZ and Vaisala radiosondes. J. Appl. Meteor. 34, 1241-1253.

Martinez, M.A., Velazquez, M., Manso, M., Mas, I., 2007. Application of LPW and SAI SAFNWC/MSG satellite products in pre-convective environments. Atmos. Res. 83, 366-379.

Miloshevich, L.M., Vomel, H., Whiteman, D.N., Lesht, B.M., Schmidlin, F.J., Russo, F., 2006. Absolute accuracy of water vapor measurements from six operational radiosonde types launched during AWEX-G and implications for AIRS validation. J. Geophys. Res. 111, D09S1010.1029/2005JD006083.

Morys, M., Mims III, F.M., Hagerup, S., Anderson, S.E., Baker, A., Kia, J., Walkup, T., 2001. Design, calibration, and performance of MICROTOPS II handheld ozone monitor and Sun photometer. J. Geophys. Res. 106 (D13), $14,573-14,582$.

Parlange, M.B., Brutsaert, W., 1990. Are radiosonde time scales appropriate to characterize boundary layer wind profiles? J. Appl. Meteor. 29, 249-255.

Plana-Fattori, A, Legrand, M. Tanré, D., Devaux, C. Vermeulen, A, 1998. Estimating the atmospheric water vapor content from sun photometer measurements. J. Appl. Meteor. 37 (8), 790-804.

Reagan, J.A., Thome, K., Herman, B., Gall, R., 1987. Water vapor measurements in the 0.94 micron absorption band - calibration, measurements and data applications. IGARSS '87. International Geoscience and Remote Sensing Symposium, Ann Arbor, MI, May 18-21, 1987. : Digest, Volume 1 (A87-53101 24-43). Institute of Electrical and Electronics Engineers, New York, pp. 63-67.
Revercomb, H.E., Turner, D.D., Tobin, D.C., Knuteson, R.O., Feltz, W.F., Barnard, 532 J., Bösenberg, J., Clough, S., Cook, D., Ferrare, R., Goldsmith, J., Gutman, S., 533 Halthore, R., Lesht, B., Liljegren, J., Linné, H., Michalsky, J., Morris, V., 534 Porch, W., Richardson, S., Schmid, B., Splitt, M., Van Hove, T., Westwater, 535 E., Whiteman, D., 2003. The ARM program's water vapor intensive 536 observation periods, overview, initial accomplishments, and future 537 challenges. Bull. Am. Meteorol. Soc. 84, 217-236.

Ross, R.J., Elliott, W.P., 1996. Tropospheric water vapor climatology and 539 trends over North America: 1973-93. J. Climate 9, 3561-3574.

Ross, R.J., Elliott, W.P., 2001. Radiosonde-based Northern Hemisphere 541 tropospheric water vapor trends. J. Climate 14, 1602-1612.

Schmid, B., Michalsky, J.J., Slater, D.W., Barnard, J.C., Halthore, R.N., 543 Liljegren, J.C., Holben, B.N., Eck, T.F., Livingston, J.M., Russell, P.B., 544 Ingold, T., Slutsker, I., 2001. Comparison of columnar water-vapor 545 measurements from solar transmittance method. Appl. Opt. 40 (12), 546 $1889-1896$.

Smirnov, A., Holben, B.N., Eck, T.F., Dubovik, O., Slutsker, I., 2000. Cloud 548 screening and quality control algorithms for the AERONET database. 549 Remote Sens. Environ. 73, 337-349.

Sola, Y., et al., 2008. Altitude effect in UV radiation during the evaluation of 551 the effects of elevation and aerosols on the ultraviolet radiation 2002552 (VELETA-2002) field campaign. J. Geophys. Res. 113, D2320210.1029/ 553 2007JD009742.

Stoew, B., Elgered, G., Johansson, J.M., 2001. An assessment of estimates of 555 integrated water vapor from ground-based GPS data. Meteorol. Atmos. 556 Phys. 77, 99-107. 557

Trenberth, K.E., Fasullo, J., Smith, L., 2005. Trends and variability in column- 558 integrated atmospheric water vapor. Clim. Dyn. 24, 741-758. 559

Zhai, P., Eskridge, R., 1996. Analyses of inhomogeneities in radiosonde 560 temperature and humidity time series. J. Climate 9, 884-896. 561 